\title{
EFFECT OF CLIMATIC CONDITIONS ON BLOOD PLASMA IgG AND LEPTIN PROFILES IN BUFFALOES
}

\author{
Y.M. Hafez \\ Animal Production Department, Faculty of Agriculture, Cairo University, Giza, Egypt \\ Corresponding author: yasseinhafez@yahoo.com
}

\section{SUMMARY}

This experiment was conducted during 2010 (August and September) in two buffalo farms located at Giza (F1) and Qena (F2) governorates. A total of 10 buffaloes (3 to 6 parities) was assigned to two experimental groups ( $n=5$ per location). Blood samples were collected fortnightly at 09:00 $h$ before feeding all the experimental animals to assess Leptin and IgG profiles as affected by Temperature Humidity Index (THI). To calculate the THI, meteorological data were collected at the two locations of the experiment.

The results demonstrated that Leptin concentration was greater $(P<0.05)$ in $F 1(4.15 \pm 0.41 \mathrm{ng} / \mathrm{ml})$ than F2 $(1.86 \pm 0.41 \mathrm{ng} / \mathrm{ml})$. There was a negative $(P<0.05)$ correlation between Leptin and THI $(r=$ -0.37). No significant $(P<0.05)$ difference in IgG levels was observed among animals in the two farms. The plasma IgG concentration in buffaloes reared at F1 (19450 $\pm 1480 \mathrm{mg} /)$ was greater than that of F2 (18439 $\pm 1480 \mathrm{mg} / \mathrm{l})$. There was no correlation between the levels of leptin hormone and total IgG.

In conclusion, the increase of heat load during August to September presented as THI on lactating buffalo decreases their leptin hormone and total IgG level in blood plasma.

Keywords: buffalo, temperature humidity index, leptin, IgG

\section{INTRODUCTION}

Egyptian buffaloes contribute about $47 \%$ and $31 \%$ of the national milk and meat production, respectively (MALR, 2010). Buffaloes are distributed along Egypt between the geographical coordinates of $20.8-32.8^{\circ} \mathrm{N}$ latitude and $25.3-35.8^{\circ} \mathrm{E}$ longitude. Thus, buffaloes suffer from heat stress in Upper Egypt relative to Delta region due to the variation in the Temperature Humidity Index (THI) which is an index that combines air temperature and relative humidity.

Summer THI in several areas of the Mediterranean basin is reported to be unfavorable to cow welfare and productivity (Segnalini et al., 2011). Buffaloes exhibit signs of great distress when exposed to direct solar radiation (Das et al., 1997 and Singh et al., 2013) due to absorption of a great deal of solar radiation for their dark skin and sparse coat (Loypetjra et al., 1987). In addition, buffaloes possess a less efficient evaporative cooling system due to their poor sweating ability (Marai and Habeeb, 2010). Effect of heat stress is aggravated when accompanied by high ambient humidity (Marai et al., 2000 \& 2007).

IgG includes circulating antibodies which act against diseases antigens. It is produced by plasma cells found within lymphatic system (Choudhary et al., 2006). Season was reported to alter serum IgG concentrations in peripheral serum of Holstein calves reared in a subtropical climate (Shearer and Beede, 1990).

Leptin is a protein hormone secreted by adipose tissues and acts on hypothalamus to regulate feed intake (Hossner, 1998 and Kim and Baik, 2004) and energy balance (Soliman et al., 2002 and Koh et al., 2008). Leptin is also associated with other biological processes such as reproduction, hematopoiesis, immune response and bone formation (Olusi et al., 2003). It has been reviewed that an increase in the circulating Leptin concentration is involved in regulation of metabolic rate, macrophage function and induction of immune cell proliferation or differentiation. Moreover, Leptin concentration in plasma has been reviewed as direct reflection of the amount of body fat and reproductive function through its effect on nutritional status (Agrawal et al., 2008).

Studying the concentrations of Leptin and IgG concentrations in the peripheral plasma of Egyptian buffaloes may be indicators to the physiological responses (disease resistance and production efficiency) condition. Up to the knowledge of the author no data are available to describe the profile of Leptin hormone and $\mathrm{IgG}$ in Egyptian buffaloes in relation to climatic conditions.

The objective of the present work was to study the effect of August and September, 2010 climatic conditions of Giza (middle Egypt) and Qena (Upper Egypt) governorates 
on the blood plasma IgG and Leptin profiles of lactating Egyptian buffaloes.

\section{MATERIALS AND METHODS}

This experiment was conducted during summer season of Egypt (from August till September 2010), simultaneously at two different dairy buffalo farms located at Giza (F1) and Qena (F2) governorates. The two governorates represented two different climatic conditions of Egypt. F1 was located at Giza (latitude $30^{\circ} 1^{\prime} 40.22^{\prime \prime} \mathrm{N}$ and longitude $31^{\circ} 11 ' 30.40 "$ E \& $12 \mathrm{~m}$ altitude), at Faculty of Agriculture, Cairo University, while the second farm (F2) was located in Qena (latitude $26^{\circ} 10^{\prime} 59.84 " \mathrm{~N}$ and longitude $32^{\circ} 44^{\prime} 24.52 \mathrm{\prime} \mathrm{E}$ \& $83 \mathrm{~m}$ altitude) belonging to Animal Production Department, Faculty of Agriculture, South Valley University.

A total of 10 multiparous lactating buffaloes (3-6 parities) at early lactation (up to 60 days postpartum) were assigned to this experiment, five from each location. Average body weight of the experimental buffaloes was $614.6 \pm 32.7$ and $640.4 \pm 32.7 \mathrm{~kg}$ for $\mathrm{F} 1$ and $F 2$, respectively with no significant differences. Housing and feeding regimen were similar in F1 and F2, where buffaloes were housed in open yards with metal roofs fences and fed alfalfa, green maize, rice straw and concentrate feed mixture according to NRC allowances (NRC, 2001). Mineral blocks and fresh drinking water were made available all the day.

\section{Environmental measures:}

Ambient temperature $\left(\mathrm{AT},{ }^{\circ} \mathrm{C}\right)$ and relative humidity (RH, \%) were measured fortnightly three times daily (09:00 h, 12:00 h and 16:00 h) under the shade using digital thermometer to the nearest $0.1{ }^{\circ} \mathrm{C}$ and the corresponding data of the climate conditions were obtained from the Central Laboratory for Agriculture Climate (CLAC), Agriculture Research Center (ARC), Ministry of Agriculture and Land Reclamation (MALR), Giza, Egypt. Ambient temperature (AT) during August and September months averaged 24.90 and $25.93{ }^{\circ} \mathrm{C}$ for $\mathrm{F} 1$ and 27.51 and $27.91{ }^{\circ} \mathrm{C}$ for $\mathrm{F} 2$. The corresponding relative humidity (RH \%) was 60.95 and $60.91 \%$ for F1 vs. 43.39 and $44.29 \%$ for F2, respectively. Climatic data were used to calculate the Temperature Humidity Index (THI) according to (Mader et al., 2006) as follow:
$\mathrm{THI}=[0.8 \times \mathrm{AT}]+[(\% \mathrm{RH} / 100) \times(\mathrm{AT}-$ 14.4)] +46.4

\section{Physiological measures}

Blood samples $(7 \mathrm{ml})$ were collected from the Jugular vein in heparinized tubes fortnightly at 09:00 $\mathrm{h}$ before morning feeding. The samples were centrifuged at $500 \times \mathrm{g}$ for 15 min at four ${ }^{\circ} \mathrm{C}$ to separate blood plasma which was stored at $-20{ }^{\circ} \mathrm{C}$ for further analysis. Blood relevant assays were executed at Hormones Laboratory, Cairo University Research Park (CURP), Faculty of Agriculture, Cairo University, Giza, Egypt.

Single radial immunodiffusion technique was used to measure the quantity of total IgG in blood plasma (Bind ARID ${ }^{\mathrm{TM}}$ Binding site limited, Birmingham, UK) according to the method described by the manufacturer.

Leptin assay was performed using ELISA reader (BIO TEK ELX808), using Leptin sandwich ELISA kit (DRG Instruments $\mathrm{GmbH}$, Germany) according to the manufacturer's guidelines. The standard curve was ranged between 0 and $100 \mathrm{ng} / \mathrm{ml}$ and the sensitivity value of the curve was reported to be $1.0 \mathrm{ng} / \mathrm{ml}$. The intra and inter assay coefficients of variability $(\mathrm{CV})$ were 5.95 and $11.55 \%$, respectively.

\section{Statistical analysis}

Data were statistically analyzed using the general linear model procedure of SAS (SAS, 2002) using the following model:

$\mathbf{Y}_{\mathrm{ijk}}=\boldsymbol{\mu}+\mathbf{F}_{\mathrm{i}}+\mathbf{M}_{\mathbf{j}}\left(\mathbf{F}_{\mathrm{i}}\right)+\mathbf{e}_{\mathrm{ijk}}$

Where: $Y_{\mathrm{ijk}}=$ an observation.

$\mu=$ overall mean.

$F_{i}=$ the fixed effect of $i^{\text {th }}$ location, $i=1,2$ whereas; $\mathrm{i}=1$ (Giza location) and $\mathrm{i}=2$ (Qena location).

$\mathrm{M}_{\mathrm{j}}\left(\mathrm{F}_{\mathrm{i}}\right)=$ the fixed effect of $\mathrm{j}^{\text {th }}$ month nested within $i^{\text {th }}$ location, $j=1,2$ whereas; $j=1$ August month and $\mathrm{j}=2$ the September month.

$\mathrm{e}_{\mathrm{ijk}}=$ experimental error assumed to be randomly distributed with $(0, \sigma e 2)$.

The Pearson's correlation coefficient test (between means) was used to calculate correlations between Leptin, IgG and THI.

\section{RESULT AND DISCUSSION Temperature Humidity Index}

The THI values during August and September in F1 and F2 were presented in Table (1), with relatively higher values in F2 by $1-4 \%$ comparing to F1. The highest THI was recorded during August in both farms.

Table 1. The average THI values at Giza (F1) and Qena (F2) locations

\begin{tabular}{lccc}
\hline Items & $\begin{array}{c}\text { Giza } \\
(\text { F1) }\end{array}$ & $\begin{array}{c}\text { Qena } \\
(\text { F2) }\end{array}$ & $\begin{array}{c}\text { Difference between } \\
\text { Giza and Qena }\end{array}$ \\
\hline August & 74.1 & 74.7 & -0.6 \\
September & 72.7 & 74.0 & -1.30 \\
\hline
\end{tabular}


Critical THI value was reported to be between 69 and 74 according to the studies of Bouraoui et al. (2002); Hahn et al. (2003) and Mader et al. (2006), which means that buffaloes during summer months were under heat stress, particularly for F2.
Analysis of diurnal change in meteorological data indicated that the heat stress reached its maximum between 12:00 and 16:00 $\mathrm{h}$ in both farms (Table 2).

Table 2. Ambient temperature (AT), relative humidity (RH) and temperature humidity index (THI) under shade at Giza (F1) and Qena (F2) locations

\begin{tabular}{lcccccc}
\hline \multirow{3}{*}{ Time } & \multicolumn{3}{c}{ Giza $(\mathbf{F 1})$} & \multicolumn{3}{c}{ Qena (F2) } \\
\cline { 2 - 7 } & $\begin{array}{c}\mathbf{A T} \\
\left({ }^{\circ} \mathbf{C}\right)\end{array}$ & $\begin{array}{c}\text { RH } \\
(\boldsymbol{\%})\end{array}$ & THI & $\begin{array}{c}\text { AT } \\
\left({ }^{\circ} \mathbf{C}\right)\end{array}$ & $\begin{array}{c}\text { RH } \\
(\boldsymbol{\%})\end{array}$ & THI \\
\hline $\mathbf{0 9 : 0 0 h}$ & 29.0 & 40.0 & 75.4 & 33.2 & 27.6 & 78.2 \\
$\mathbf{1 2 : 0 0 h}$ & 31.7 & 35.5 & 77.9 & 36.5 & 23.0 & 80.6 \\
$\mathbf{1 6 : 0 0 h}$ & 30.2 & 54.6 & 79.2 & 35.9 & 23.2 & 80.1 \\
Average & $\mathbf{3 0 . 3}$ & $\mathbf{4 3 . 4}$ & $\mathbf{7 7 . 5}$ & $\mathbf{3 5 . 2}$ & $\mathbf{2 4 . 6}$ & $\mathbf{7 9 . 6}$ \\
\hline
\end{tabular}

\section{Leptin hormone}

The obtained results of leptin hormone for experimental buffaloes in F1 and F2 during August and September months were represented in Table (3). The overall mean of
Leptin concentrations in buffalo cows reared in $\mathrm{F} 1$ was higher $(\mathrm{P}<0.05)$ than buffaloes of $\mathrm{F} 2$ with difference of $2.29 \mathrm{ng} / \mathrm{ml}$, which is about $55 \%$ less than F2.

Table 3. Leptin hormone (ng/ml) of lactating buffaloes $(\bar{\chi} \pm \mathrm{SE})$ during August and September months in Giza (F1) and Qena (F2) locations

\begin{tabular}{lll}
\hline Items & Giza (F1) & Qena (F2) \\
\hline August & $4.24^{\mathrm{a}} \pm 0.63$ & $1.63^{\mathrm{b}} \pm 0.63$ \\
September & $4.06^{\mathrm{a}} \pm 0.51$ & $2.10^{\mathrm{b}} \pm 0.51$ \\
Overall mean & $4.15^{\mathrm{a}} \pm 0.41$ & $1.86^{\mathrm{b}} \pm 0.41$ \\
\hline
\end{tabular}

Means with different superscripts between the two locations $(\mathrm{a}, \mathrm{b})$ differ significantly $(\mathrm{P}<0.05)$

No significant effect was found between the two months within each location. Leptin concentrations tended to decrease in September compared to August for buffaloes in F1 with a reverse trend for F2 (by a difference of $-0.18 v s .+0.47 \mathrm{ng} / \mathrm{ml})$. Negative $(\mathrm{P}<0.05)$ correlation was observed between Leptin concentration and THI $(r=-0.37)$ as shown in Table (4).

Table 4. Average blood plasma IgG concentration (mg/l) of lactating buffaloes $(\bar{\chi} \pm \mathrm{SE})$ during August and September months in Giza (F1) and Qena (F2) locations

\begin{tabular}{lcc}
\hline Items & Giza (F1) & Qena (F2) \\
\hline August & $10209^{\mathrm{ay}} \pm 2293$ & $12188^{\mathrm{by}} \pm 2293$ \\
September & $28690^{\mathrm{ax}} \pm 1872$ & $24690^{\mathrm{bx}} \pm 1872$ \\
Overall mean & $19450 \pm 1480$ & $18439 \pm 1480$ \\
\hline Means with different & superscripts between the two locations $(\mathrm{a}, \mathrm{b})$ and within each location (x, y) differ \\
significantly $(\mathrm{p}<0.05)$ & &
\end{tabular}

The concentration of Leptin in buffaloes reared in both studied farms (F1 and F2) was less than that mentioned by Tajik and Nazifi (2011). The low concentration of Leptin during August is in agreement with the results of Mann et al. (2000) who reported that Leptin reached a nadir in late summer (August to September.), while being at its peak in late winter (January to March). This is because of the critical role of Leptin in regulating energy metabolism (Block et al., 2003) and reducing dry matter intake (Hansen, 1997; Drew, 1999 and Ronchi et al., 2001) under heat stress.
Hence, Leptin is positively correlated with net energy balance of ruminants (Blache et al., 2000 and Tokuda and Yano, 2001), so the observed decrease in Leptin during August and in F2 (compared to F1) is most probably due to the value of THI to control heat production (Accorsi et al., 2005).

\section{IgG concentration}

Results presented in Table (5), indicated no significant $(\mathrm{P}<0.05)$ difference in IgG levels between F1 and F2, however there was slightly 
higher IgG value for buffaloes in $F 1$ comparing to those in F2. On the month level, there were significant differences in $\mathrm{IgG}$ between the two months within the two locations.

Table 5. Correlation coefficients among THI, Leptin and IgG

\begin{tabular}{lcc}
\hline Items & Leptin & IgG \\
\hline THI & $\mathbf{- 0 . 3 6 6 0 2}$ & $\mathbf{- 0 . 2 0 7 4 8}$ \\
& $(0.0089)$ & $(0.1482)$ \\
Leptin & & $\mathbf{0 . 0 4 1 0 6}$ \\
& & $(0.7771)$ \\
\hline
\end{tabular}

Between parentheses is the probability at level 5\%

Under heat stress where feed intake is reduced (West, 2003 and Hansen, 2004), animals are being susceptible to infection. The trend of decreasing IgG in F2 compared to F1 comes close to the results of Kelly et al. (1982), Shearer and Beede (1990), Lacetera and Bernabucci (2000), and Westra and Wahyudi (2009) reporting a reduction in total IgG in the blood of dairy cattle under heat stress compared to moderate climate.

There was no correlation between the level of leptin hormone and total $\operatorname{IgG}(\mathrm{r}=0.04)$, Table (4). This result was in agreement with Choudhary et al. (2006), who showed that no significant association was found between Leptin and serum IgG concentrations in cattle calves.

It may be indicated that the role of Leptin on immune system might be because of its association with some other determinant of immunity (cellular) e.g. interleukin 11 \& 12 and T-cell and not with IgG (Agarwal et al., 2009).

It could be concluded that heat load on buffaloes decreases Leptin hormone, while it had no effect on IgG in blood plasma of Egyptian buffalo under the prevailing experimental conditions of this study. Further studies might be needed to determine the effect of heat stress on different metabolic hormones and immune mediators in order to increase the productive and reproductive performance of buffaloes under the stressful summer months in Egypt.

\section{REFERENCES}

Accorsi, P. A., N. Govoni, R. Gaiani, C. Pezzi, E. Seren, and C. Tamanini, 2005. Leptin, $\mathrm{GH}, \mathrm{PRL}$, Insulin and metabolic parameters throughout the dry period and lactation in dairy cows. Reproduction of Domestic Animals, 40: 217-223.

Agrawal, R., P. K. Rout and S. K. Singh, 2009. Leptin: A biomolecule for enhancing livestock productivity. Indian Journal of Biology, 8: 169-176.

Blache, D., L. M. Chagas, M. A. Blackberry, P. E. Vercoe, and G. B. Martin, 2000. Metabolic factors affecting the reproductive axis in male sheep. Journal of Reproduction and Fertility, 120: 1-11.

Block, S. S., J. M. Smith, R. A. Ehrhardt, M. C. Diaz, R. P. Rhoads, M. E. Van Amburgh, and Y. R. Boisclair, 2003. Nutritional and developmental regulation of plasma leptin in dairy cattle. Journal of Dairy Science, 86: 3206-3214.

Bouraoui, R., M. Lahmar, A. Majdoub, M. Djemali, and R. Belyea, 2002. The relationship of temperature-humidity index with milk production of dairy cows in a Mediterranean climate. Animal Research, 51: 479-491.

Choudhary, V., P. Kumar, V. K. Saxena, and T. K. Bhattacharya, B. Bhushan, A. Sharma and K. A. Ahmed, 2006. Effect of leptin and IGFBP-3 gene polymorphisms on serum IgG level of cattle calves. AsianAustralian Journal of Animal Science, 19(8): 1095-1099.

Das, S.K., R. C. Upadhyay and M. L. Madan, 1997. Changes in skin temperature and physiological reactions in Murrah buffalo during solar exposure in summer. AsianAustralian Journal of Animal Science, 10(5): 478-483.

Drew, B., 1999. Practical nutrition and management of heifers and high yielding dairy cows for optimal fertility. Cattle Practice, 7: 243-248.

Hahn, G. L., T. L. Mader, and R. A. Eigenberg, 2003. Perspective on development of thermal indices for animal studies and management. European Association of Animal Production technical series, 7: 3-44.

Hansen, P. J., 1997. Strategies for enhancing reproduction of lactating dairy cows exposed to heat stress. Page 62-67 in: Proceeding of the $16^{\text {th }}$ Annual Conference of American Embryo Transfer Association Madison, USA.

Hansen, P. J., 2004. Physiological and cellular adaptations of zebu cattle to thermal stress. Animal Reproduction Science, 82-83: 349360.

Hossner, K. L., 1998. Cellular, molecular and physiological aspects of leptin: Potential 
application in animal production. Canadian Journal of Animal Science, 78: 463-472.

Kelly, K. W., C. Osborne, J. Evermann, S. Parish, and C. Gaskins, 1982. Effects of chronic heat and clod stressors on plasma immunoglobulin and mitogen-induced blastogenesis in calves. Journal Dairy Science, 65: 1514-1528.

Kim, K. S. and M. G. Baik, 2004. Production of leptin in E. coli and its effect on glucose and acetate transport and expression of uncoupling protein-2 gene in adipose tissues of Korean cattle (Hanwoo). AsianAustralian Journal of Animal Science, 17: 1062-1068.

Koh, K. K., S. M. Park, and M. J. Quon, 2008. Leptin and cardiovascular disease: response to therapeutic interventions. Circulation 117: 3238-3249

Lacetera, N. and U. Bernabucci, 2000. The production of dairy cows in a hot climate. Informatore-Agrario, 56(31): 39-41.

Loypetjra, P., N. Chaiyabutr, S. Usanakornkul and A. Pichaicharnarong, 1987. Water buffalo. In: H. D. Johnson (Ed.), Bioclimatology and the adaptation of livestock, Elsevier, Amsterdam, The Netherlands. Part III, Chapter 8, pp. 107125.

Mader, T. L., M. S. Davis, and T. BrownBrandl, 2006. Environmental factors influencing heat stress in feedlot cattle. Journal of Animal Science, 84: 712-719.

MALR, 2010. Ministry of Agriculture and Land Reclamation, Economic Affairs Sector, Study of Statistics for Animal, Poultry and Fish Wealth, p. 1-50.

Mann, D. R., M. A. Akinbami, K. G. Gould, and V. D. Castracane, 2000. A longitudinal study of leptin during development in the male rhesus monkey: the effect of body composition and season on circulating leptin levels. Biology of Reproduction, 62: 285-291.

Marai, I. F. M. and A. A. M. Habeeb, 2010. Buffalo's biological functions as affected by heat stress. Livestock Science, 127: 89109.

Marai, I. F. M., L. B. Bahgat, T. H. Shalaby, and M. A. Abdel-Hafez, 2000. Fattening performance, some behavioral traits and physiological reactions of male lambs fed concentrates mixture alone with or without natural clay under hot summer of Egypt. Annals of Arid Zone (India), 39: 449-460.

Marai, I. F. M., A. A. El-Darawany, A. Fadiel, and M. A. M. Abdel-Hafez, 2007. Physiological traits as affected by heat stress in sheep. Small Ruminant Research, 71: $1-12$.
NRC, 2001. Nutrient Requirements of Dairy Cattle .The $7^{\text {th }}$ review edition of National Academy Press, Washington, DC, USA, $381 \mathrm{pp}$.

Olusi S., A. Al-Awadhi, C. Abiaka, M. Abraham, and S. George, 2003. Serum copper levels and not zinc are positively associated with serum leptin concentrations in the healthy adult population. Biology of Trace Elements Research, 91: 137-144.

Overton, T. R. and M. R. Waldron, 2004. Nutritional management of transition dairy cows: strategies to optimize metabolic health. Journal of Dairy Science, 87(13): 105-199.

Ronchi, B., G. Stradaioli, A. Verini Supplizi, U. Bernabuci, N. Lacetera, and P. A. Accorsi, 2001. Influence of heat stress or feed restriction on plasma progesterone, oestradiol-17 beta, LH, FSH, prolactin and cortisol in Holstein heifers. Livestock Production Science, 68: 231-41.

Segnalini, M., A. Nardone, U. Bernabucci, A. Vitali, B. Ronchi and N, Lacetera, 2011. Dynamics of the temperature-humidity index in Mediterranean basin. International Journal of Biometeorology, 55: 253-263.

Shearer, J. K. and D. K. Beede, 1990. Effects of high environmental temperature on production, reproduction and health of dairy cattle. Agriculture-Practice, 11: 1-8.

Singh, M., B. K. Chaudhari, J. K. Singh, A. K. Singh and P. K. Maurya, 2013. Effects of thermal load on buffalo reproductive performance during summer season. Journal of Biological Sciences, 1(1): 1-8.

Soliman, M., K. Ishioka, R. Yoshida, K. Komabayashi, H. Hatai, Y. Matsui, T. Hirai, S. Katagiri, Y. Takahashi, Y. Kawakita, H. Abe, H. Kitamura, K. Kimura, and M. Saito, 2002. Serum leptin levels during the periparturient period in cows. Journal of Veterinary Medical Sciences, 64: 1053-1056.

Tajik, J. and S. Nazifi, 2011. A study of correlation of serum leptin with trace elements in water buffalo (Bubalus bubalis). Pakistani Veterinary Journal, 31(3): 231-234.

Tokuda, T. and H. Yano, 2001. Blood leptin concentrations in Japanese black cattle. Animal Science Journal, 72: 309-313.

West, J. C., 2003. Effect of heat stress on production in dairy cattle. Journal of Dairy Science, 86: 2131-1244.

Westra, I. and I. Wahyudi, 2009. The effects of tropical climate stressor on gamma immunoglobulin concentration of serum and colostrum of dairy cows of first and second parity. Animal Production, 11 (3): 143-148. 
تأثير الظروف المناخية على تركيز الجلوبيولينات المناعية و هرمون اللبتين ببلازما دم الجاموس

ياسين محمد حافظ

قسم الإنتاج الحيوانس، كلية الزراعة، جامعة القاهرة، الجبزة، مصر

اجريت هذه الدراسة خلال شهرى أغسطس وسبتمبر 2010، بهدف دراسة تأثير الظروف المناخية فى هذه الفترة على تركيز

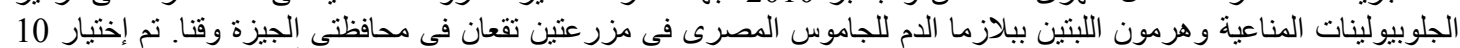

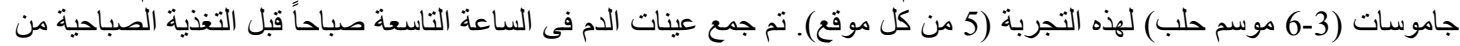

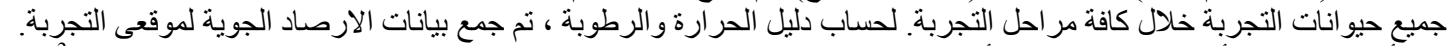

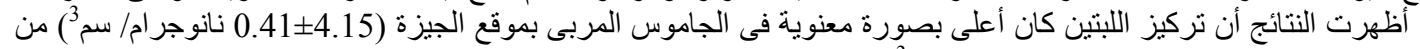

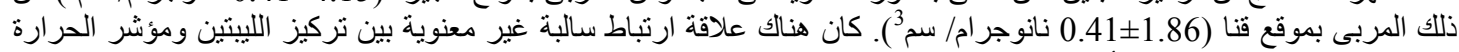

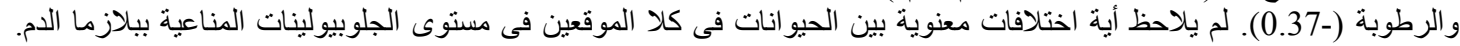

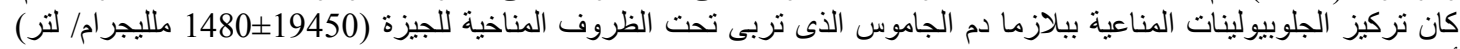

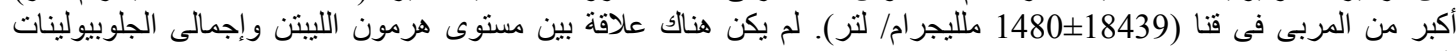

تبين الدراسة أن زيادة الحمل الحرارى على الجاموس تقلل من هرمون الليبتن ومستوى إجمالى الجلوبيولينات المناعية فى بلازما 